\section{Estimated Costs and Investment Analysis of Producing and Harvesting Muscadine Grapes in the Southeastern United States}

\author{
Carlos E. Carpio ${ }^{1}$, Charles D. Safley ${ }^{2,4}$, and E. Barclay Poling ${ }^{3}$
}

ADDITIONAL INDEX WORDS. Vitis rotundifilia, economic analysis, irrigation, trellis systems

SuMMARY. This study estimates and compares the production costs and profitability of muscadine grape (Vitis rotundifilia) production under the single-wire (SW) and the Geneva double curtain (GDC) trellis systems with and without drip irrigation. Profitability analysis revealed that muscadine grape production can be a profitable venture. Irrigated muscadine grape vineyards were shown to be more profitable than nonirrigated vineyards. The comparison of the GDC trellis system and the SW trellis system indicates that the GDC trellis system is more profitable. Returns to land and management from muscadine grapes grown under the GDC system were found to be less sensitive to changes in prices and yields than the returns from muscadine grapes grown under the SW trellis system. Net returns from irrigated systems were also found to be less sensitive to variations in prices and yields than nonirrigated systems. The estimated total costs of establishing (Years 0-3) a muscadine grape vineyard were between $\$ 9783$ /acre and $\$ 15,065 /$ acre depending on the production system used. For the GDC production system, which was the most profitable production system, the estimated return to land and management was $\$ 447 /$ acre. Cash flow analysis demonstrated that the payback period for this system can be achieved in the 10th year, whereas the net present value of the investment was estimated at $\mathbf{\$ 4 4 8 4}$ and the internal rate of return was estimated at $9.6 \%$.

$\mathrm{M}$ uscadine grapes are native to the southeastern United States. Currently, these grapes are produced in 12 southeastern states and account for $\approx 5000$ acres (Cline and Fisk, 2006). The acres devoted to muscadine varieties have showed substantial increases in the region. For example, in North Carolina, the acreage devoted to muscadine grapes has grown from 346 acres in 2002 to a 2005 level of $\approx 1300$ acres (Cline and Fisk, 2006; North Carolina Agricultural Statistics and Consumer Services, 2002; North Carolina Muscadine Grapes Growers Association, 2006).

Fresh muscadine grapes have enjoyed a niche for decades in the southeast. In recent years, processed products made out of muscadine

${ }^{1}$ Assistant Professor, Department of Applied Economics and Statistics, Clemson University, Clemson, SC 29634-0313

${ }^{2}$ Professor, Department of Agricultural and Resource Economics, North Carolina State University, Campus Box 8109, 4328 Nelson Hall, NCSU-ARE, Raleigh, NC 27695-8109.

${ }^{3}$ Professor, Department of Horticultural Science, North Carolina State University, Raleigh, NC 27695-7609.

${ }^{4}$ Corresponding author. E-mail: charles_safley@ ncsu.edu. grapes such as wines, juice, and nutraceuticals have also gained interest attributable in part to potential health benefits. Recent studies have found that muscadine grapes contain more resveratrol and other antioxidants than any other type of grapes (Ector et al., 1996; North Carolina Wine and Grape Council, 2007).

Budgets for producing muscadines are available (Krewer et al., 2002; Noguera et al., 2005), but they only consider one trellis system and one level of irrigation. This study estimates and compares the production costs and profitability of four production systems, which result from the combination of two trellis systems and two levels of irrigation.
The economic analysis also includes a breakeven analysis, which allows growers to determine price and yield necessary to recoup their costs. The production systems considered include the single-wire (SW) and the Geneva double curtain (GDC) trellis systems with and without drip irrigation.

Four studies have examined the effects of irrigation on muscadine grapes (Carpio and NeSmith, 2006; Clark and Spiers, 2001), but only one has considered the economic aspects of this cultural practice. Three studies have looked into the effect of the training system on the yield of muscadine grapes (Andersen et al., 1985; Austin et al., 1988; Brightwell and Austin, 1975), but none of these studies compared the profitability of muscadine grapes grown using different trellis systems.

The results of this study are intended to serve as guides to assist individuals entering the muscadine grapes industry and help those who are currently growing muscadine grapes to make more informed management decisions. Specific objectives were: 1) to estimate the typical costs associated with growing, harvesting, and marketing muscadine grapes; 2) to evaluate the effect of varying price and yield; 3 ) to evaluate the profitability of establishing a muscadine grape vineyard; and 4) to compare the profitability of growing muscadine grapes with and without drip irrigation under the SW and GDC training systems.

\section{Materials and methods}

The cost model was developed using Excel (Microsoft Corp., Redmond, WA). Production practices were based on typical management procedures recommended by production specialists (e.g., Poling et al.,

\begin{tabular}{llll}
\hline $\begin{array}{l}\text { Units } \\
\begin{array}{l}\text { To convert U.S. to SI, } \\
\text { multiply by }\end{array}\end{array}$ & U.S. unit & SI unit & $\begin{array}{l}\text { To convert SI to U.S., } \\
\text { multiply by }\end{array}$ \\
\hline 0.4047 & acre(s) & ha & 2.4711 \\
0.3048 & $\mathrm{ft}$ & $\mathrm{m}$ & 3.2808 \\
3.7854 & gal & $\mathrm{L}$ & 0.2642 \\
0.7457 & horsepower & $\mathrm{kW}$ & 1.3410 \\
2.54 & inch(es) & $\mathrm{cm}$ & 0.3937 \\
0.4536 & $\mathrm{lb}$ & $\mathrm{kg}$ & 2.2046 \\
6.8948 & $\mathrm{psi}$ & $\mathrm{kPa}$ & 0.1450 \\
0.9072 & ton $(\mathrm{s})$ & $\mathrm{t}$ & 1.1023 \\
2.2417 & ton/acre & $\mathrm{t} \cdot \mathrm{ha}^{-1}$ & 0.4461 \\
$\left({ }^{\circ} \mathrm{F}-32\right) \div 1.8$ & ${ }^{\circ} \mathrm{F}$ & ${ }^{\circ} \mathrm{C}$ & $\left(1.8 \times{ }^{\circ} \mathrm{C}\right)+32$
\end{tabular}


2003 ) and farmers who are currently growing North Carolina's main bronze muscadine variety, Carlos. This variety is mainly grown for processing and accounts for $\approx 90 \%$ of all the muscadine acreage planted in the state (Cline and Fisk, 2006). North Carolina lies between $33^{1} 2^{\circ}$ and $37^{\circ} \mathrm{N}$ latitude and between $75^{\circ}$ and $84^{1 / 2}{ }^{\circ} \mathrm{W}$ longitude; however, commercial muscadine grape production is primarily confined to areas of the state below $36^{\circ} \mathrm{N}$ latitude and between $75^{\circ}$ and $81^{\circ} \mathrm{W}$ longitude. Commercial production is not recommended in the mountains of North Carolina nor in the foothills or Upper Piedmont areas where there is a high probability of winter temperatures falling below $10{ }^{\circ} \mathrm{F}$. The most critical consideration in choosing a planting site for muscadine production in the coastal plane, which is the primary production area, is internal soil drainage. Although wild muscadine grapes survive on a wide variety of soils, commercial producers must select a well-drained soil (Poling et al., 2003).

Cost and price estimates correspond to 2005 average prices and were based on a representative 10acre vineyard with a 20 -year productive life. It was assumed that the vineyard was rectangular in shape and the land relatively flat. The vines were positioned in two production regions, each $330 \times 660 \mathrm{ft}$, with a total of 55 rows in each region. In addition, the vineyard included $40-\mathrm{ft}$ turn rows for machinery operations and a $30-\mathrm{ft}$ central alley. Altogether, the vineyard included 10 acres of production space and 1.7 acres for the turn rows and the central alley for a total of 11.7 acres.

SINGLE-WIRE TRELLIS SYSTEM. In this system, the vines were planted every $20 \mathrm{ft}$ and the rows were spaced $10 \mathrm{ft}$ apart for a total of 218 vines per acre. This spacing resulted in 66 rows of vines in each production region. The bracing and interior support posts were $8 \mathrm{ft}$ long, whereas it was assumed that the " $\mathrm{H}$ " bracing system would require two 5- to 6-inch (diameter) posts at the end of the rows. A 4inch $\times 4$-inch $\times 6$-ft pressure-treated timber or 4 -inch $\times 6$ - $\mathrm{ft}$ post was also placed between the tops of the two bracing posts (see Poling et al., 2003 for more details about trellis systems).

Geneva double Curtain TRELLIS SYSTEM. The vines in this trellis system were planted every 20 $\mathrm{ft}$ and the rows were spaced $12 \mathrm{ft}$ apart. This spacing resulted in a total of 182 vines/acre with 55 rows of vines planted in each production region. The bracing system for the GDC trellis was very similar to the SW trellis system; however, there are some differences in the dimensions of the posts required for the braces. Specifically, the inside bracing posts are only $6.5 \mathrm{ft}$ long and an additional timber $(2 \times 2 \times 45$ inches $)$ was needed over the bracing post connectors (Poling et al., 2003).

Each trellis system was assumed to have a zero salvage value at the end of the productive life of the vineyard. A detailed description of the costs for the materials, equipment, and labor required for the construction of both trellis systems is presented in Table 1 .

IRRIGATION COSTS. It was assumed that each vine would require
$10 \mathrm{gal} /$ week of water in the first year, $20 \mathrm{gal} /$ week the second year, and 30 $\mathrm{gal} / \mathrm{week}$ in the third year and thereafter (Clark and Spiers, 2001). It was also assumed that the water source was a pond and the system was designed to irrigate each of the 5 -acre production areas simultaneously using four $1-\mathrm{gal} / \mathrm{h}$ emitters per vine. Similar to the trellis systems, the irrigation system was assumed to have a zero salvage value at the end of the productive life of the vineyard. A description of the costs for the equipment as well as the costs needed to design and install the irrigation system for each type of trellis is presented in Table 2.

The cash costs of operating the irrigation systems (taxes, insurance, repair, and energy) were calculated following Buchanan and Cross (2002). Annual taxes were estimated as $1 \%$ of the initial costs of the equipment,

Table 1. Estimated $\operatorname{costs}^{\mathrm{z}}$ for the materials, equipment, and labor of the trellis system for a 10 -acre $(4.0 \mathrm{ha})$ muscadine grapes vineyard in the southeastern United States.

\begin{tabular}{|c|c|c|c|c|}
\hline Item $^{y}$ & Quantity & Unit & $\begin{array}{c}\text { Cost } \\
(\$ / \text { unit })\end{array}$ & $\begin{array}{c}\text { Total } \\
\text { cost }(\$)\end{array}$ \\
\hline \multicolumn{5}{|c|}{ Single-wire trellis system } \\
\hline Treated posts $(4$ inches $\times 8 \mathrm{ft})$ & 2,180 & Each & 5.00 & $10,900.00$ \\
\hline Treated posts $(6$ inches $\times 8 \mathrm{ft})$ & 528 & Each & 7.00 & $3,696.00$ \\
\hline \multicolumn{5}{|l|}{ Treated timbers $(4$ inches $\times$} \\
\hline 4 inches $\times 6 \mathrm{ft})$ & 264 & Each & 5.00 & $1,320.00$ \\
\hline Wire, 100-lb rolls of \#9 galvanized & 30 & Rolls & 74.00 & $2,220.00$ \\
\hline Staples & 50 & Lbs & 0.80 & 40.00 \\
\hline Total materials & & & & $18,176.00$ \\
\hline Equipment & & & & $1,795.35$ \\
\hline Labor & & & & $4,422.00$ \\
\hline Total cost & & & & $24,393.35$ \\
\hline \multicolumn{5}{|c|}{ Geneva double curtain trellis system } \\
\hline Treated posts $(4$ inches $\times 8 \mathrm{ft})$ & 1,820 & Each & 5.00 & $9,100.00$ \\
\hline $\begin{array}{l}\text { Treated posts }(6 \text { inches } \times 8 \mathrm{ft}) \\
\quad(\text { end brace posts })\end{array}$ & 220 & Each & 7.00 & $1,540.00$ \\
\hline $\begin{array}{l}\text { Treated posts }\left(6 \text { inches } \times 6^{1 / 2} \mathrm{ft}\right) \\
\quad \text { (inside brace posts) }\end{array}$ & 220 & Each & 9.40 & $2,068.00$ \\
\hline Treated timbers $(4$ inches $\times$ & & Each & & \\
\hline 4 inches $\times 6 \mathrm{ft})$ & 220 & & 5.00 & $1,100.00$ \\
\hline Wire, 100-lb rolls of \#9 galvanized & 45 & Roll & 74.00 & $3,330.00$ \\
\hline Metallic crossarms & 1,820 & Each & 6.50 & $11,830.00$ \\
\hline Spreader $(2 \times 4 \times 45$ inches $)$ & 220 & Each & 2.00 & 440.00 \\
\hline Galvanized bolt $(3 / 8 \times 8$ inches $)$ & 1,820 & Each & 0.80 & $1,456.00$ \\
\hline Bolts $(3 / 16$ inch $)$ & 220 & Each & 0.24 & 52.80 \\
\hline Staples & 10 & $\mathrm{Lb}$ & 0.80 & 8.00 \\
\hline Total materials & & & & $30,924.80$ \\
\hline Equipment & & & & $1,500.59$ \\
\hline Labor & & & & $6,831.00$ \\
\hline Total cost & & & & $39,256.39$ \\
\hline
\end{tabular}


insurance costs as $0.5 \%$ of the initial costs of the equipment, and annual repair costs as $5 \%$ of the initial costs of the equipment. To calculate the irrigation energy costs, the following information was used: a flow rate of 85 horsepower, a total head of $56 \mathrm{psi}$, a pump efficiency of 0.80 , and an electricity cost of $\$ 0.08 \mathrm{~kW}$-h. The equations needed to calculate energy costs are presented in Buchanan and Cross (2002). Labor requirements were estimated at $6 \%$ of the total irrigation time (Turner and Anderson, 1980).

LABOR COSTS. The estimated hours of labor required for each operation that involved machinery and equipment were increased by a factor of 1.2 to account for the time needed for setup, adjustment, and to move the equipment to the vineyard (Edwards, 2002). Hired employees were paid $\$ 10.56 / \mathrm{h}$. This figure is meant to be representative of the "true" costs of labor and not just the base wage rate. This labor rate included a base wage rate of $\$ 8.25 / \mathrm{h}$ plus the required payroll expenses (e.g., workers' compensation, unemployment, and FICA taxes and other overhead expenses). The 2005 average wage rate for farm labor paid in North Carolina was obtained from the Farm Labor Report published by the National Agricultural Statistics Service (U.S. Department of Agriculture, 2005).

MACHINERY COSTs. For purposes of this study, it was assumed that all the machinery and equipment were purchased new at 2005 purchase prices. The machinery and equipment used in this budget reflect machinery components that can be used for other farming enterprises in addition to growing muscadine grapes (Table 3 ). Therefore, only $20 \%$ of the total cost of the machinery was assumed to correspond to the vineyard. The exceptions to this were the blast sprayer and the irrigation equipment, which are used solely for muscadine grapes. Moreover, because the disk and the chisel plow are only used for land preparation, it was further assumed that they were rented. The mechanical pruner was also assumed to be rented at a rate of $\$ 85 /$ acre, which was the average price paid in 2005 by muscadine grape producers.

To calculate the cash operating costs of the machinery, we followed Edward's (2002) procedure for farm machinery costs estimation. The cash

Table 2. Estimated $\operatorname{costs}^{\mathrm{z}}$ for the materials, design, and installation of a drip irrigation system for a 10 -acre (4.0 ha) muscadine grapes vineyard in the southeastern United States.

\begin{tabular}{|c|c|c|c|c|}
\hline \multirow[b]{2}{*}{ Item/description ${ }^{\mathrm{y}}$} & \multicolumn{2}{|c|}{$\mathbf{S W}^{\mathrm{x}}$} & \multicolumn{2}{|c|}{$\mathrm{GDC}^{\mathrm{w}}$} \\
\hline & Quantity & Costs $(\$)$ & Quantity & Costs $(\$)$ \\
\hline Design of the irrigation system & 1 & 250.00 & 1 & 250.00 \\
\hline Electric pump ( 5 horsepower $)$ & 1 & $1,999.83$ & 1 & $1,999.83$ \\
\hline Media filter set ( 18 inches) & 1 & $3,418.85$ & 1 & $3,418.85$ \\
\hline $\begin{array}{l}\text { Drip tubing }(0.7 \times 0.6 \text { inch }) \text {, } \\
1000-\mathrm{ft} \text { rolls }\end{array}$ & 44 & $3,715.18$ & 37 & $3,124.13$ \\
\hline $\begin{array}{l}\text { Pressure compensated emitters } \\
\quad(1 \mathrm{gal} / \mathrm{h})\end{array}$ & 8,720 & $2,554.10$ & 7,280 & $2,132.31$ \\
\hline Other materials & 1 & $4,178.24$ & 1 & $4,150.00$ \\
\hline Installation & 1 & $7,000.00$ & 1 & $7,000.00$ \\
\hline Total & & $23,116.20$ & & $22,103.36$ \\
\hline
\end{tabular}

${ }^{\mathrm{z}}$ Costs were estimated based on 2005 prices.

${ }^{\mathrm{y}} \mathrm{l}$ horsepower $=0.7457 \mathrm{~kW} ; \mathrm{l}$ inch $=2.54 \mathrm{~cm} ; \mathrm{l} \mathrm{ft}=0.3048 \mathrm{~m} ; \mathrm{l} \mathrm{gal}=3.7854 \mathrm{~L}$.

${ }^{\mathrm{x}} \mathrm{SW}=$ single-wire trellis system.

${ }^{\mathrm{w}} \mathrm{GDC}=$ Geneva double curtain trellis system.

Table 3. Estimated purchase prices, ${ }^{\mathrm{z}}$ salvage value, years of life, and annual hours of use for machinery and equipment for the production of 10 -acre (4.0 ha) muscadine grapes vineyard in the southeastern United States.

\begin{tabular}{|c|c|c|c|c|c|}
\hline Year & Machinery description $^{y}$ & $\begin{array}{l}\text { Purchase } \\
\text { price }(\$)\end{array}$ & $\begin{array}{c}\text { Salvage } \\
\text { value }(\$)\end{array}$ & $\begin{array}{c}\text { Life } \\
\text { (years) }\end{array}$ & $\begin{array}{l}\text { Annual } \\
\text { use (h) }\end{array}$ \\
\hline 0 & Tractor (30 horsepower) & 12,500 & 2,500 & 20 & 500 \\
\hline 0 & Tractor (60 horsepower) & 25,000 & 5,000 & 20 & 500 \\
\hline 0 & Spot sprayer & 190 & 72 & 12 & 50 \\
\hline 0 & $\begin{array}{l}\text { Fertilizer spreader/seed } \\
\text { broadcaster }\end{array}$ & 395 & 99 & 12 & 100 \\
\hline 0 & Tine chisel plow $(7 \mathrm{ft})^{\mathrm{x}}$ & 2,500 & 625 & 15 & 125 \\
\hline 0 & $\operatorname{Disc}(9 \mathrm{ft})$ & 3,500 & 875 & 15 & 125 \\
\hline 0 & Utility trailer & 2,000 & 500 & 15 & 100 \\
\hline \multirow[t]{2}{*}{0} & Pickup & 25,000 & 6,250 & 10 & 650 \\
\hline & Total preparation year & $65,085^{z}$ & & & \\
\hline 1 & Soil auger + drive connector & 498 & 125 & 15 & 50 \\
\hline 1 & Post driver & 2,374 & 594 & 15 & 50 \\
\hline 1 & Boom sprayer & 700 & 266 & 12 & 100 \\
\hline 1 & Pruning equipment & 1,000 & 100 & 12 & 100 \\
\hline 1 & Poer-takeoff blast sprayer & 4,000 & 1,520 & 12 & 100 \\
\hline 1 & Rotary mower $(7 \mathrm{ft})$ & 2,000 & 500 & 10 & 100 \\
\hline \multirow[t]{2}{*}{1} & $\begin{array}{l}\text { Drip irrigation system } \\
\text { and pump }\end{array}$ & - & - & 20 & 300 \\
\hline & Total first year & 10,572 & & & \\
\hline
\end{tabular}

z2005 prices.

${ }^{\mathrm{y}} \mathrm{l}$ horsepower $=0.7457 \mathrm{~kW} ; \mathrm{l} \mathrm{ft}=0.3048 \mathrm{~m}$

${ }^{x}$ The tine chisel plow and the disc were not included in this summation; however, the information on purchase price was used to calculate the cost per hour.

"See Table 2 .

costs/hour includes property taxes ( $1 \%$ of purchase price), insurance ( $0.5 \%$ of purchase price), repair, fuel, and lubricants costs. Lubricants costs were assumed to be $15 \%$ of fuel costs.

OTHER COSTS AND PRICES. The prices of the materials used to produce muscadine grapes were obtained from local dealers who regularly supply North Carolina muscadine growers. Prices for the vines were obtained as the average price from several nurseries in North Carolina.
Harvesting was assumed to be carried out in September. In 2005, muscadine grape producers were charged an average of $\$ 100 /$ ton for custom harvesting. These costs include the harvesting and transportation costs to the winery, but the owner of the muscadine grape vineyard is required to provide a tractor. We used a base price of $\$ 500 /$ ton for the price received by the growers, which was the processor contract price in 2005 . 
Because every commodity should contribute to the financial success of a farm, a fee was charged to the muscadine grapes enterprise for the overall farm overhead expenses and operating capital. Because land values vary throughout the region, a land charge was not included in this budget. However, growers should include a land charge that is representative of current land values in their region. Owners should also charge a management fee to the enterprise to account for their managerial ability in supervising the overall operation.

Yield Assumptions. The yield assumptions were based on information provided by producers and on the results of horticultural studies, which account for the effects of irrigation and the trellis system on yields (Andersen et al., 1985; Brightwell and Austin, 1975; Mortensen, 1981; $\mathrm{NeSmith}, 2005$ ). The expected yield patterns over the 20-year life of the muscadine operations, for the four systems of production, are shown in Table 4 . These patterns assumed average environmental conditions and that the first harvest was achieved in the second year of production. The yields obtained increase gradually, reach a maximum in the fourth year, and continue at that level thereafter.

To calculate the effect of irrigation on yields, we used the results from two studies comparing the yields of irrigated and nonirrigated muscadine grapes (Mortensen, 1981; NeSmith, 2005). These studies reported an average increase in yield of $30 \%$ resulting from the use of irrigation. For our calculations, we used a more conservative $20 \%$ increase in yields resulting from irrigation.

Data concerning the influence of training systems on the yields of muscadine grapes are limited. Furthermore, no study compares the SW trellis system and the GDC system. Consequently, we used data from two different studies to estimate the difference in yields between these two training systems. Brightwell and Austin (1975) evaluated the performance of muscadine grapes in the onewire and the two-wire trellis systems for 20 years. They found that vines in the two-wire trellis systems produced $34 \%$ higher yields than in the onewire system. Andersen et al. (1985), on the other hand, compared the yields obtained from the two-wire vertical trellis and the GDC system. They reported that vines trained to the GDC system had an average increase in yield of $11 \%$ compared with the two-wire vertical training system. Therefore, we assumed that yields in the GDC system are 30\% higher than in the one-wire trellis system.

\section{Results and discussion}

Capital investment for the machinery and equipment for the establishment and operation of the muscadine planting were estimated to be $\$ 65,085$ for the preparatory year and $\$ 10,572$ for the first year (Table 3). The capital investment for the irrigation systems was estimated to be $\$ 23,116$ for the vineyard with SW trellis system and $\$ 22,103$ for the GDC trellis system (Table 2). Purchase of most of the equipment for land preparation and planting occurs in the preparation year. Construction of the trellis system was estimated to cost $\$ 2439$ /acre for the SW trellis and $\$ 3926$ /acre for the GDC trellis system.

The system with the lowest establishment costs (Years 0-3) was the SW trellis system without

Table 4. Projected annual muscadine grapes yields under four production systems in the southeastern United States.

\begin{tabular}{lcccc}
\hline \multirow{2}{*}{$\begin{array}{l}\text { Production } \\
\text { year }\end{array}$} & $\begin{array}{c}\text { Projected annual yield (ton/acre) } \\
\text { no irrigation }\end{array}$ & $\begin{array}{c}\text { SW with } \\
\text { drip irrigation }\end{array}$ & $\begin{array}{c}\text { GDC }^{\mathrm{x}} \text { with } \\
\text { no irrigation }\end{array}$ & $\begin{array}{c}\text { GDC with } \\
\text { drip irrigation }\end{array}$ \\
\hline $0^{\mathrm{w}}$ & 0 & 0 & 0 & 0 \\
1 & 0 & 0 & 0 & 0 \\
2 & 0.8 & 1 & 1 & 1.2 \\
3 & 2.4 & 3 & 3.1 & 3.7 \\
4 and older & 6.4 & 8 & 8.3 & 10.0 \\
\hline
\end{tabular}

${ }^{2} 1$ ton $/$ acre $=2.2417 \mathrm{t} \cdot \mathrm{ha}^{-1}$.

${ }^{y} \mathrm{SW}=$ single-wire trellis system.

${ }^{\mathrm{x}} \mathrm{GDC}=$ Geneva double curtain trellis system

wear $0=$ preparation year. irrigation, which had an estimated price tag of $\$ 9783 /$ acre. The system with the highest establishment costs was the GDC trellis system with irrigation, which cost an estimated $\$ 15,065 /$ acre. For the trellis systems that used irrigation, the materials, labor, and machinery costs each accounted for $\approx 30 \%$ of the total establishment costs. For the systems without irrigation, the materials made up $\approx 40 \%$ of the total establishment costs, whereas labor accounted for $30 \%$ and machinery comprised $20 \%$ of the establishment costs. Approximately $70 \%$ of the establishment costs were incurred during the preparation year (Year 0) and the first year of production.

The total cost of producing and harvesting grapes in an established vineyard (Year 4 of production and thereafter) was estimated to be $\$ 3125$ /acre for the single trellis system with no irrigation, $\$ 3754$ /acre for the SW trellis system with irrigation, $\$ 3798$ for the GDC trellis system without irrigation, and \$4416/ acre for the GDC trellis system with irrigation (Table 5). Cost recovery of the vineyard establishment costs was the largest cost category associated with producing and harvesting mature muscadine grapes, accounting for an average of $29 \%$ of the total costs (Table 5). Harvesting was the second most expensive cost category, comprising an average of $22 \%$ of the total costs, followed by labor costs with an average of $20 \%$, equipment costs with an average of $16 \%$, and material costs with an average of $13 \%$. The vineyard establishment costs were allocated using the cost recovery (annuity) method as suggested by the American Agricultural Economics Association (2000). These calculations assumed a 20-year amortization period and a $7 \%$ nominal interest rate.

Monthly expenses. The estimated monthly expenses for the major cost categories are included to give growers an idea of the potential annual cash flow obligations. Only the expenses for the SW trellis system with drip irrigation are presented, but the cost structure was similar for each of the four production systems (Table 6). Growers should estimate these monthly cash flow requirements for their individual situations before 
Table 5. Estimated equipment, materials, labor, harvesting, establishment, and total costs of producing and harvesting 1 acre $(0.4$ ha) of mature (Year 4 and thereafter) muscadine grapes grown under four production systems in the southeastern United States.

\begin{tabular}{lcccrrrc}
\hline & \multicolumn{6}{c}{ Costs $(\$ / \text { acre })^{\mathrm{y}}$} & \\
\cline { 2 - 7 } $\begin{array}{l}\text { Production } \\
\text { system }^{\mathbf{z}}\end{array}$ & Equipment & Materials & Labor & Harvest & Establishment $^{\mathrm{x}}$ & $\begin{array}{c}\text { Total } \\
\text { costs }\end{array}$ \\
\hline SW + NI & 535.09 & 497.49 & 590.34 & 640.00 & 861.81 & $3,124.73$ \\
SW + DI & 643.41 & 497.49 & 698.05 & 800.00 & $1,114.67$ & $3,753.62$ \\
GDC + NI & 535.09 & 497.49 & 855.20 & 832.00 & $1,078.66$ & $3,798.45$ \\
GDC + DI & 636.76 & 497.49 & 962.91 & $1,000.06$ & $1,318.54$ & $4,415.76$ \\
\hline
\end{tabular}

${ }^{2}$ The production systems results from combining the single-wire (SW) and the Geneva double curtain (GDC) trellis systems with drip irrigation (DI) and without irrigation (NI).

y $\$ 1.00 /$ acre $=\$ 2.4711 /$ ha.

${ }^{x}$ Cost recovery of establishment costs.

planting muscadine grapes to ensure that they know how much money must be available to meet their financial obligations. In addition, a lending agency may require the grower to provide information to determine the appropriate repayment schedule if the grower has to secure a financial loan.

Over $95 \%$ of the total estimated costs in the preparation year were spent in November and December to purchase the muscadine plants and the trellis supplies. Activities carried out in March and May accounted for $37 \%$ and $26 \%$ of the total cost per acre in the first year, respectively. The March activities included constructing the trellis and digging the holes to plant the vines, whereas the vines were planted, the growth tubes were installed, and the vines were trained in May. In the second year, January and May had the most expenses because these are the months in which the vines need to be trained and pruned. Together these 2 months accounted for $48 \%$ of the total expenses in the second year.

In the third year, January and August accounted for $42 \%$ of the total production costs, primarily as a result of the manual pruning; and September accounted for $16 \%$ of the total costs resulting from the harvest expenses. In the fourth through the 20 th years, September made up 32\% of the total expenditures, again resulting from the harvest expenses; and January, which is the month in which pruning occurs, comprised $24 \%$ of the total costs.

Monthly Labor estimates. The annual labor estimates for 1 acre of muscadine grapes grown using the SW trellis system with drip irrigation are presented in Table 7. Labor requirements in the preparation year totaled 7.8 person-hours, whereas 167 person-hours were needed in the first year, 89 person-hours in the second year, 64 person-hours in the third year, and 68 person-hours in the fourth year when the vines reached full production. The first year was the most labor-intensive year as a result of the labor needed to construct the trellis in March and train the vines in May, June, and July. In the second year, January and May are the most labor-intensive months as a result of the amount of time needed to prune and train the vines. Starting in the third year, the majority of the labor was needed in January for the dormant pruning when the vines were pruned by hand. Any summer pruning that was needed was assumed to be accomplished using a mechanical pruner.

Adding drip irrigation to either production system had a relatively minor impact on the total labor requirements. For both the SW trellis and the GDC system, only an additional 10.2 person-hours per year were needed for the fourth through the 20th years of production as a result of adding drip irrigation. The impact of switching from a SW trellis to a GDC trellis system was larger. Labor demands for the GDC system were 24 person-hours per year larger than those for the SW trellis, primarily as a result of the higher requirements for pruning labor.

M U S C A D INE VINEYAR D PRofitabiLITy. When judging the profitability of an enterprise, it is important not only to see how many dollars the enterprise yields, but also when the dollars come in and the returns are available for other enterprises. There are two principles to consider. First, the sooner a dollar of revenue comes in, the sooner it can be used to earn more revenue. Second, for any two enterprises of equal risk, the one yielding the higher rate of return is usually preferable. We will look at the flow of funds in the muscadine business to show both profitability and cash position (solvency).

After subtracting expenses from revenues in each year, the flow of funds, or net cash flow, pattern emerges (Table 8). Farmers establishing new muscadine grapes plantings will experience net outflows of cash during the first 4 years. The income stream becomes positive during the fourth year of production. Table 8 shows the net cash flow for muscadine grapes grown under a SW trellis system with drip irrigation, but similar tables were constructed for the other systems of production.

First, we consider the year of payback, or the year in which growers finally get their investment back in terms of cash flow. The payback period is also an important consideration in arranging financing if growers must secure loans to cover the period in which the enterprise operates in a deficit cash position. Specifically, the payback period represents the time needed to generate enough revenues to cover startup expenses. The payback period for the SW trellis system without irrigation is Year 13 and Year 12 for grapes grown using the same trellis system and drip irrigation (Table 9). The payback period for the GDC trellis system without irrigation is Year 11 and Year 10 for grapes grown using the GDC trellis system with drip irrigation. These results indicate that even though higher investments are necessary to establish the GDC trellis system, the corresponding higher yields allow the grower to recover the investment 2 years sooner compared with the SW trellis systems under the same level of irrigation. Adding drip irrigation yields similar results. That is, the addition of drip irrigation to either trellis system can reduce the payback period for that trellis system by 1 year.

The next step is to compare the net revenue stream with other opportunities. There are two ways to do this. The first way is to assume that farmers could invest their money elsewhere 
Table 6. Estimated monthly and annual equipment, material, labor, and total production cost of producing and harvesting 1 acre ( 0.4 ha) of muscadine grapes on a farm in the southeastern United States (single-wire trellis system with drip irrigation).

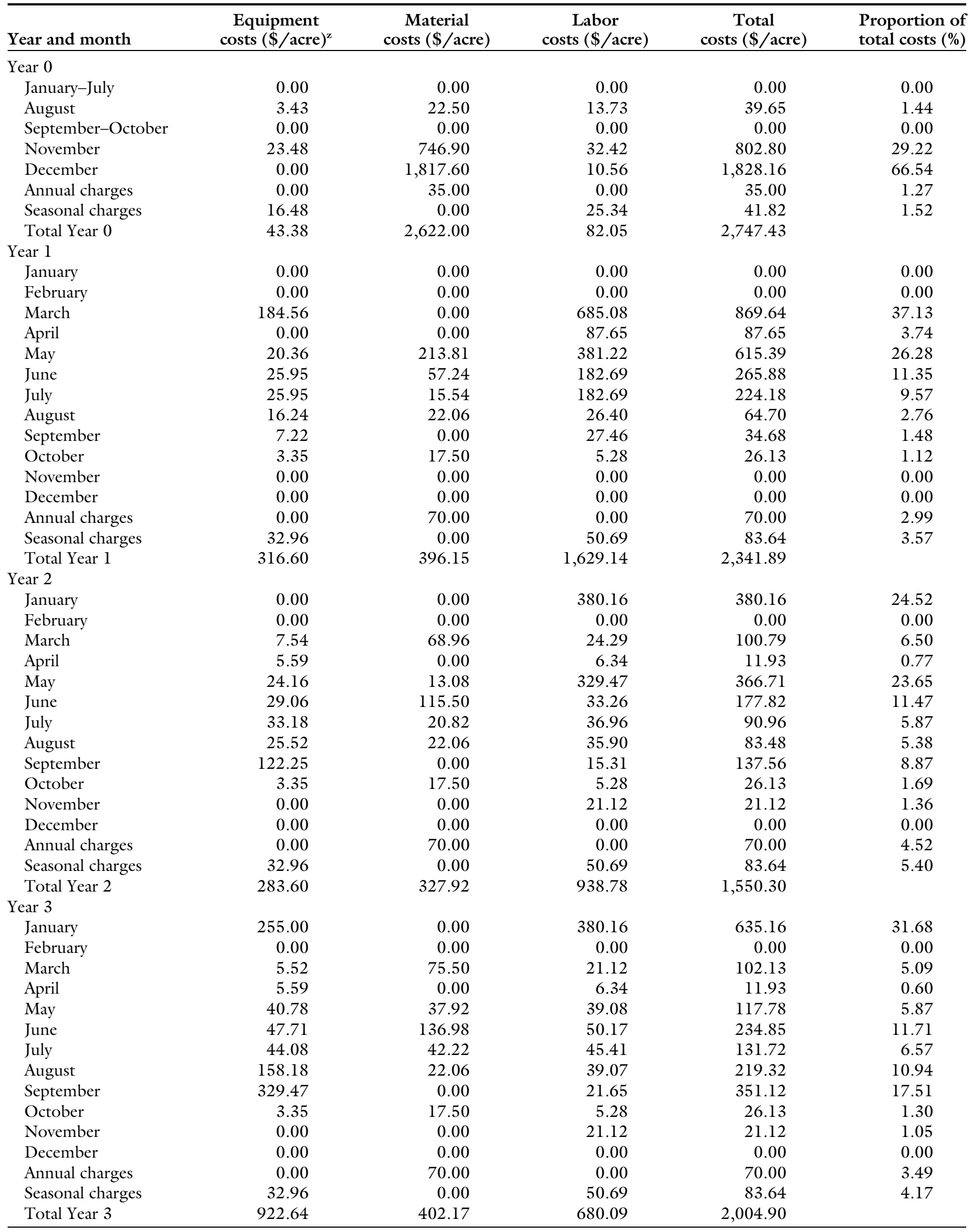


Table 6. (Continued) Estimated monthly and annual equipment, material, labor, and total production cost of producing and harvesting 1 acre ( 0.4 ha) of muscadine grapes on a farm in the southeastern United States (single-wire trellis system with drip irrigation).

\begin{tabular}{|c|c|c|c|c|c|}
\hline Year and month & $\begin{array}{c}\text { Equipment } \\
\text { costs }(\$ / \text { acre })^{\mathrm{z}}\end{array}$ & $\begin{array}{c}\text { Material } \\
\text { costs }(\$ / \text { acre })\end{array}$ & $\begin{array}{c}\text { Labor } \\
\text { costs }(\$ / \text { acre })\end{array}$ & $\begin{array}{c}\text { Total } \\
\text { costs }(\$ / \text { acre })\end{array}$ & $\begin{array}{l}\text { Proportion of } \\
\text { total costs (\%) }\end{array}$ \\
\hline \multicolumn{6}{|l|}{ Year 4} \\
\hline January & 255.00 & 0.00 & 380.16 & 635.16 & 24.07 \\
\hline March & 5.52 & 95.12 & 21.12 & 121.75 & 4.61 \\
\hline April & 5.59 & 0.00 & 6.34 & 11.93 & 0.45 \\
\hline July & 47.71 & 42.39 & 47.53 & 137.62 & 5.22 \\
\hline August & 158.18 & 22.06 & 39.07 & 219.32 & 8.31 \\
\hline September & 829.47 & 0.00 & 21.65 & 851.12 & 32.25 \\
\hline October & 3.35 & 17.50 & 5.28 & 26.13 & 0.99 \\
\hline November & 0.00 & 0.00 & 21.12 & 21.12 & 0.80 \\
\hline December & 0.00 & 0.00 & 0.00 & 0.00 & 0.00 \\
\hline
\end{tabular}

${ }^{2} \$ 1.00 /$ acre $=\$ 2.4711 /$ ha.

at a given interest rate such as $6 \%$ and compare the muscadine enterprise with this other investment. The interest rate selected for this analysis should represent the "best" low-risk alternative such as a long-term certificate of deposit available for off-farm investments. For a single enterprise, the essence of the net present value (NPV) approach is that the project should be accepted if its NPV is greater than zero. This method uses the discounting procedure to compare the value of a dollar at the time of the planting decision with a dollar received for muscadine grapes at some future time. Discounting is based on the concept that a dollar received in the future is worth less than a dollar received today. For example, $\$ 1000$ received 10 years from now is worth $\$ 558$ received today at a $6 \%$ interest rate.

Today's cash-equivalent value of applying land and management to muscadine grapes for a $6 \%$ interest rate is $\$ 135 /$ acre for the SW trellis system without irrigation, \$1567/ acre for the SW trellis system under irrigation, \$2591/acre for a GDC trellis without irrigation, and \$4484/ acre for the GDC trellis system with

Table 7. Estimated annual and monthly labor requirements needed to grow and harvest 1 acre ( 0.4 ha) of muscadine grapes on a farm in the southeastern United States (single-wire trellis with drip irrigation).

\begin{tabular}{|c|c|c|c|c|c|}
\hline \multirow[b]{3}{*}{ Month } & \multicolumn{5}{|c|}{ Year } \\
\hline & Preparation year & 1 & 2 & 3 & 4 \\
\hline & \multicolumn{5}{|c|}{ Estimated labor requirement (person-hours) } \\
\hline January & 0.00 & 0.00 & 36.00 & 36.00 & 36.00 \\
\hline February & 0.00 & 0.00 & 0.00 & 0.00 & 0.00 \\
\hline March & 0.00 & 76.60 & 2.30 & 2.00 & 2.00 \\
\hline April & 0.00 & 8.30 & 0.60 & 0.60 & 0.60 \\
\hline May & 0.00 & 36.10 & 31.20 & 3.70 & 4.70 \\
\hline June & 0.00 & 17.30 & 3.15 & 4.75 & 5.25 \\
\hline July & 0.00 & 17.30 & 3.50 & 4.30 & 4.50 \\
\hline August & 1.30 & 2.50 & 3.40 & 3.70 & 3.70 \\
\hline September & 0.00 & 2.60 & 1.45 & 2.05 & 2.05 \\
\hline October & 0.00 & 0.50 & 0.50 & 0.50 & 0.50 \\
\hline November & 3.07 & 0.50 & 2.00 & 2.00 & 4.00 \\
\hline December & 1.00 & 0.50 & 0.00 & 0.00 & 0.00 \\
\hline General activities & 2.40 & 4.80 & 4.80 & 4.80 & 4.80 \\
\hline Total & 7.77 & 167.00 & 88.90 & 64.40 & 68.10 \\
\hline
\end{tabular}

irrigation. The figure is interpreted in just one way, but the interpretation can be phrased in several ways. At an interest rate of $6 \%$, for example: 1) a new, 1 -acre muscadine planting using a SW trellis system with irrigation is worth $\$ 1567 /$ acre today; and 2) if a farmer was just about to establish a muscadine grapes planting, someone would have to pay him $\$ 1567$ to persuade him to forget the plans. Under these assumptions, muscadine planting using the GDC trellis system with drip irrigation is the most profitable production system.

The second method for financial comparison of the muscadine grape enterprise with other opportunities is to calculate the internal rate of return (IRR) on the total investment in muscadine grapes and then compare this rate of return with the interest yields on other investments. In this analysis, muscadine production was compared with 20-year constant maturity U.S. Treasury bonds, which are a low-risk investment. The IRR to an investment in the muscadine enterprise was $6.18 \%$ for the SW trellis system without irrigation, $7.58 \%$ for the SW trellis system with irrigation, $8.58 \%$ for the GDC trellis system without irrigation, and $9.58 \%$ for the GDC trellis system under irrigation. With dividends on the 20-year U.S. Treasury bonds currently yielding $\approx 4.25 \%$, all these returns are higher. Of course, revenues from muscadine 
Table 8. Estimated annual yields, gross revenues, costs, net and accumulated cash flows for 1 acre (0.4 ha) of muscadine grapes under a single-wire trellis system with drip irrigation over a 21 -year production period for a representative farm in the southeastern United States.

\begin{tabular}{ccccrr}
\hline Year & $\begin{array}{c}\text { Annual yield } \\
\text { (ton/acre) }\end{array}$ & $\begin{array}{c}\text { Total } \\
\text { costs }\end{array}$ & $\begin{array}{c}\text { Gross } \\
\text { revenue }\end{array}$ & $\begin{array}{c}\text { Net cash } \\
\text { flow }\end{array}$ & $\begin{array}{c}\text { Accumulated } \\
\text { cash flow }\end{array}$ \\
\cline { 2 - 6 } $0^{\mathrm{x}}$ & 0.00 & $3,839.13$ & 0.00 & $-3,839.13$ & $-3,839.13$ \\
1 & 0.00 & $5,224.95$ & 0.00 & $-5,224.95$ & $-9,064.09$ \\
2 & 1.00 & $1,550.30$ & 500.00 & $-1,050.30$ & $-10,114.39$ \\
3 & 3.00 & $2,004.90$ & $1,500.00$ & -504.90 & $-10,619.28$ \\
4 & 8.00 & $2,638.95$ & $4,000.00$ & $1,361.05$ & $-9,258.24$ \\
5 & 8.00 & $2,638.95$ & $4,000.00$ & $1,361.05$ & $-7,897.19$ \\
6 & 8.00 & $2,638.95$ & $4,000.00$ & $1,361.05$ & $-6,536.14$ \\
7 & 8.00 & $2,638.95$ & $4,000.00$ & $1,361.05$ & $-5,175.09$ \\
8 & 8.00 & $2,638.95$ & $4,000.00$ & $1,361.05$ & $-3,814.04$ \\
9 & 8.00 & $2,638.95$ & $4,000.00$ & $1,361.05$ & $-2,453.00$ \\
10 & 8.00 & $3,043.95$ & $4,000.00$ & 956.05 & $-1,496.95$ \\
11 & 8.00 & $2,638.95$ & $4,000.00$ & $1,361.05$ & -135.90 \\
12 & 8.00 & $2,993.91$ & $4,000.00$ & $1,006.09$ & 870.19 \\
13 & 8.00 & $2,638.95$ & $4,000.00$ & $1,361.05$ & $2,231.24$ \\
14 & 8.00 & $2,638.95$ & $4,000.00$ & $1,361.05$ & $3,592.28$ \\
15 & 8.00 & $2,712.03$ & $4,000.00$ & $1,287.97$ & $4,880.25$ \\
16 & 8.00 & $2,638.95$ & $4,000.00$ & $1,361.05$ & $6,241.30$ \\
17 & 8.00 & $2,638.95$ & $4,000.00$ & $1,361.05$ & $7,602.35$ \\
18 & 8.00 & $2,638.95$ & $4,000.00$ & $1,361.05$ & $8,963.40$ \\
19 & 8.00 & $2,638.95$ & $4,000.00$ & $1,361.05$ & $10,324.45$ \\
20 & 8.00 & $2,143.40$ & $4,000.00$ & $1,856.60$ & $12,181.05$ \\
\hline & & & & & \\
15 & 2.00 & & & &
\end{tabular}

${ }^{2} 1$ ton $/$ acre $=2.2417 \mathrm{t} \cdot \mathrm{ha}^{-1}$

${ }^{\mathrm{y}} 1.00 /$ acre $=\$ 2.471 \mathrm{l} / \mathrm{ha}$

${ }^{x}$ Year $0=$ preparation year.

Table 9. Estimated payback period, net present value, and internal rate of return for 1 acre $(0.4 \mathrm{ha})$ of muscadine grapes under four production systems for a representative farm in the southeastern United States.

\begin{tabular}{lccc}
\hline & $\begin{array}{c}\text { Payback period } \\
\text { (years) }\end{array}$ & $\begin{array}{c}\text { Net present } \\
\text { value (\$/acre }\end{array}$ & $\begin{array}{c}\text { Internal rate of } \\
\text { return (\%) }\end{array}$ \\
\cline { 2 - 4 } Production system $^{\mathrm{z}}$ & 13 & $\mathbf{5 0 0 / \text { ton } ^ { \mathbf { x } }}$ & \\
\hline SW + NI & 12 & 135.09 & 6.18 \\
SW + DI & 11 & $1,567.46$ & 7.58 \\
GDC + NI & 10 & $2,590.99$ & 8.58 \\
GDC + DI & $4,483.56$ & 9.58 \\
\hline
\end{tabular}

${ }^{z}$ The production systems results from combining the single-wire (SW) and the Geneva double curtain (GDC) trellis systems with drip irrigation (DI) and without irrigation (NI).

${ }^{y} \$ 1.00 /$ acre $=\$ 2.4711 /$ ha.

$\mathrm{x} \$ 1.00 /$ ton $=\$ 0.9072 / \mathrm{t}$.

grapes are frequently more risky as a result of price fluctuations and weather conditions.

RETURNS TO LAND AND MANAGEMENT. The net returns to land and management will depend on the marketable yield and the price growers receive for their grapes. Table 10 presents the net returns of a mature muscadine grape operation for various prices and marketable yields under the four production systems analyzed in this study.

Under the assumed average yields for mature grapes (shown in irrigation have higher returns to land and management than the production systems without irrigation.

To analyze the sensitivity of the results to different price and yield assumptions, the estimated returns were also calculated assuming different prices and yields (Table 10). Prices ranged from a low of $\$ 400 /$ ton to a high of $\$ 600 /$ ton and yield estimates were calculated at $5 \%$ and $10 \%$ above and below the average yields assumed for mature vines. Total expenses per acre were adjusted to account for the varying yields. The sensitivity analysis also shows the breakeven yield, which is the yield that would be necessary to cover the total production costs at the given price level.

Generally, growers would not receive a positive return for any of the four production systems unless the price of grapes was at least $\$ 500 /$ ton. The only exception would be for the SW trellis system with drip irrigation in which a positive return would be received if the yield was at least 8.8 tons/acre and the price was $\$ 450 /$ ton. If the price of grapes were above $\$ 500 /$ ton, a positive return would be realized for each system at every yield level that was considered in this study. If grape prices equaled $\$ 500 /$ ton, both GDC trellis systems would generate positive returns at every yield level, whereas the SW trellis systems would generate negative returns at the lower yield levels.

As part of the sensitivity price analysis, we also computed breakeven prices and shutdown prices. The breakeven price is the price that just covers the total costs of production, and the shutdown price is the price that only covers the variable costs of production. Therefore, it would be in the grower's best financial interests to stop production if the price of grapes reached the shutdown price. Both sets of prices were calculated at the average yield levels. The breakeven prices for the SW trellis system with and without drip irrigation were $\$ 488.24$ /acre and $\$ 469.20$ /acre, respectively. The breakeven prices for the GDC trellis system without irrigation was $\$ 456.54$ /acre and $\$ 441.55 /$ acre for the GDC trellis system with drip irrigation.

The shutdown price for each production system was well below 
Table 10. Estimated returns to land and management $(\$ / \text { acre })^{\mathrm{z}}$ received from growing and harvesting muscadine grapes under four production systems on a farm in the southeastern United States for various prices and marketable yields.

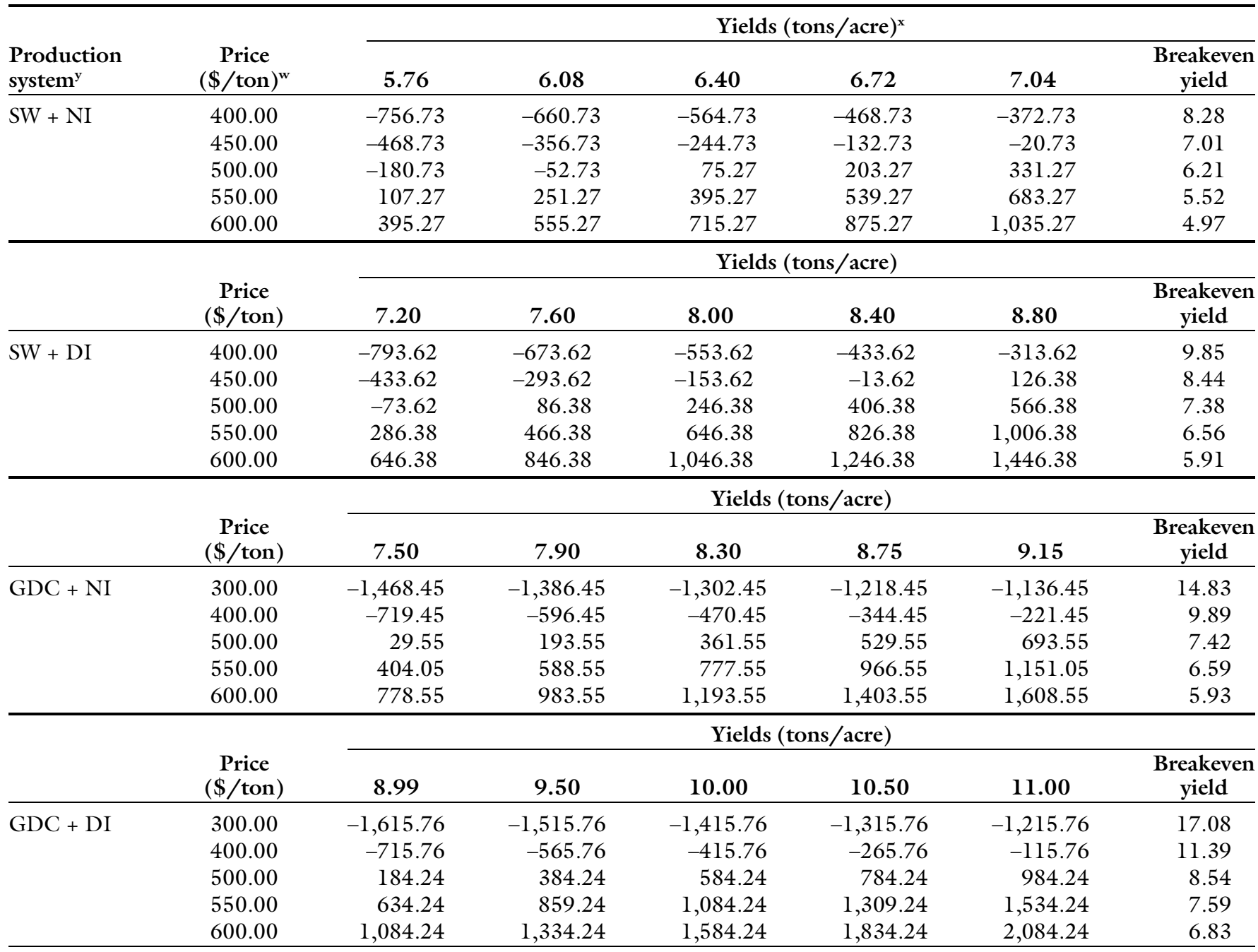

${ }^{2} \$ 1.00 /$ acre $=\$ 2.4711 /$ ha.

The production systems results from combining the single-wire (SW) and the Geneva double curtain (GDC) trellis systems with drip irrigation (DI) and without irrigation (NI).

${ }^{\mathrm{x}} \mathrm{l}$ ton $/$ acre $=2.2417 \mathrm{t} \cdot \mathrm{ha}^{-1}$.

w $\$ 1.00 /$ ton $=\$ 0.9072 / \mathrm{t}$.

the base price of $\$ 500 /$ ton. The shutdown price was estimated to be $\$ 323.14$ /acre for the SW trellis without irrigation and $\$ 305.51 /$ acre for the SW trellis with drip irrigation. The shutdown price for the GDC trellis system without irrigation was $\$ 300.94$ /acre and $\$ 288.11 /$ acre for the GDC trellis system with drip irrigation. Overall, the returns to land and management were less sensitive to changes in prices in the GDC trellis systems than in the SW systems. Likewise, the net returns in the irrigated production systems were less sensitive to price changes than in the systems without irrigation.

This analysis also revealed that the GDC system was usually less sensitive to decreases in yields. Breakeven yields in the GDC system without and with irrigation were $10 \%$ and $14 \%$, respectively, below each system's projected annual yield. Corresponding breakeven yields for the SW trellis systems were $3 \%$ and $10 \%$ below the projected annual yields for the nonirrigated and irrigated systems, respectively.

Like in most farming operations, growers do have a tremendous influence on their crop yields. The more they know about their crop and the better job they do in caring for the crop, the more likely they will have higher yields of high-quality fruit. On the other hand, local markets will determine the maximum price for which growers can sell their grapes.

\section{Conclusions and recommendations}

Profitability analysis revealed that muscadine grape production can be a profitable venture. Irrigated muscadine grape vineyards were shown to be more profitable than nonirrigated vineyards. The comparison of the GDC trellis system and the SW trellis system indicates than the GDC trellis system is more profitable. Returns to land and management from muscadine grapes grown under the GDC system were found to be less sensitive to changes in prices and yields than 
the returns from muscadine grapes grown under the SW trellis system. Net returns from irrigated systems were also found to be less sensitive to variations in prices and yields than nonirrigated systems.

The estimated total costs of establishing (Years 0-3) a muscadine grape vineyard were between $\$ 9783$ / acre and $\$ 15,065 /$ acre depending on the production system used. For the GDC production system, which was the most profitable production system, the estimated return to land and management was $\$ 447 /$ acre. Cash flow analysis demonstrated that the payback period for this system can be achieved in the 10th year, whereas the NPV of the investment was estimated at $\$ 4484$ and the IRR was estimated at $9.58 \%$.

This budget is only a guide and is not a substitute for growers calculating their own costs and breakeven year. Costs can vary from one producer to another because of market conditions, labor supply, age and condition of the machinery and equipment, education, managerial skills, and many other factors. Because every grower's situation is different, it is recommended that each grower estimate their individual production, marketing, and harvest costs based on their own production techniques, price expectations, and local market situation.

\section{Literature cited}

American Agricultural Economics Association. 2000. Commodity costs and returns estimation handbook. A report of the AAEA Task Force on commodity costs and returns. 22 Aug. 2005. $<$ http://www.economics.nrcs.usda.gov/ care $/$ aaea $/>$.

Andersen, P., M. Bryan, and L.H. Baker. 1985. Effect of two wire vertical and Geneva double curtain training systems on berry quality and yield of muscadine grapes. Proc. Florida State Hort. Soc. 98:175-178.

Austin, M.E., K. Bondari, and W.T. Brightwell. 1988. Effects of plant spacing, trellis system, irrigation, fertilizer rate, and spur thinning on the yield of muscadine grapes. Georgia Agr. Expt. Sta. Res. Bul. 368 .

Brightwell, W.T. and M.E. Austin. 1975. Influence of trellis type on yield of muscadine grape. J. Amer. Soc. Hort. Sci. 100:374-376.

Buchanan, J.R. and T.L. Cross. 2002. Irrigation cost analysis handbook. Agr. Ext. Serv, University of Tennessee, PB1721. 8 Aug. 2005. <http://www. utextension.utk.edu/publications/ pbfiles/PB1721.pdfs.

Carpio, C. and D.S. NeSmith. 2006. Economic assessment of irrigation management in muscadine grapes. HortTechnology 16:478-482.

Clark, J.R. and J.M. Spiers. 2001. Irrigation and mineral nutrition, p. 169-187. In: Basiouny, F.M. and D.G. Himelrick (eds.). Muscadine grapes. ASHS Crop Production Series, Alexandria, VA.

Cline, B. and C. Fisk. 2006. Overview of muscadine grape acreage, cultivars and production areas in the southeastern U.S. Muscadine Grape Workshop for Cooperative Extension Agents, 2006. The Southern Region Small Fruit Consortium. 25 July 2007. <http://www. smallfruits.org/CoAgentTraining/ Sept06Training/NolMuscadine_acres_ and_cultivars.pdf $>$.

Ector, B.J., J.B. Magee, C.P. Hegwood, and M.J. Coign. 1996. Resveratrol concentration in muscadine berries, juice, pomace, purees, seeds and wines. Amer. J. Enol. Viticult. 47:57-62.

Edwards, W. 2002. Estimating farm machinery costs. Iowa State Univ. 3 Aug. 2005. <www.extension.iastate.edu/ agdm/crops/html/a3-29.html>.

Krewer, G., M. Hall, D.S. NeSmith, D. Horton, H. Sherm, P. Sumner, T. Tyson, and G. Westberry. 2002. Commercial muscadine culture. Coop. Ext. Serv. Univ. Georgia College Agr. Sci. Bul. 379.

Mortensen, J.A. 1981. Irrigation system for grapes. Proc. Viticult. Sci. Symp. Florida A\&M Univ. 3:7-12.

NeSmith, D.S. 2005. Muscadine grape response to drip irrigation rate. HortScience 40:799-801.

Noguera, E., J. Morris, K. Striegler, and M. Thomsen. 2005. Production budgets for Arkansas wine and juice grapes. Arkansas Agr. Expt. Sta. Res. Rpt. 976. 22 Aug. 2005. <http://www.uark.edu/depts/ agripub/Publications/bulletins / 976.pdfs.

North Carolina Agricultural Statistics and Consumer Services. 2002. 2002 North Carolina commercial fruit inventory survey. 8 Mar. 2007. <http://www.ncagr. $\mathrm{com} /$ stats/fruit/fruitweb.pdf>.

North Carolina Muscadine Grapes Growers Association. 2006. North Carolina muscadine statistics. 8 Mar. 2007. <http://www.ncmuscadine.org/Pages/ Statistics-Page.htm>.

North Carolina Wine and Grape Council. 2007. Muscadine grapes, wine and health. 25 July $2007 .<$ http://www.ncwine.org/ muscadine/muscadineHealth.html>.

Poling, E.B., C.M. Mainland, W.T. Bland, B. Cline, and K.A. Sorensen. 2003. Muscadine production guide for North Carolina. North Carolina Coop. Ext. Serv. North Carolina State Univ. 19 Oct. 2005. <http://www.smallfruits. org/Muscadines/production / MuscadineGuide2003.pdfs.

Turner, J.H. and C.L. Anderson. 1980. Planning for an irrigation system. 2nd ed. American Association for Vocational Instructional Materials, Athens, GA.

U.S. Department of Agriculture. 2005. Farm labor. 22 Aug. 2005. <http:// usda.mannlib.cornell.edu/usda/nass/ FarmLabo//2000s /2005/FarmLabo08-19-2005.pdfs. 